\title{
Overview of the French organic sector of oilseeds and protein crops $^{\text {मे }}$
}

\author{
Charlotte Canale*, Françoise Labalette and Céline Ruiz-Le Guillou \\ Terres Univia, l'interprofession des huiles et protéines végétales, 11 rue de Monceau, 75008 Paris, France
}

Received 4 October 2020 - Accepted 6 October 2020

\begin{abstract}
To respond to the demand of organic products for feed (oilmeals, protein crops) and food (oil, dry pulses), organic oilseed and protein crops surfaces are increasing rapidly in France. Terres Univia, the interbranch organisation which represents French oilseed and oil fruit sector and French high protein crops sector interests, carried out a comprehensive 2-year survey in 2016 and 2017 on the different actors of the organic production chain from the collectors to feed and food users. The study showed that organic sector was, at this time, well organized but that it had to face some challenges to meet up with the scale up of organic sectors. Collectors must ensure outlets and prices for producers, accompanying the choice and technical management of production crops. They need to reach a better matched between offer and demand to reduce their logistic cost by, for example, contracting with the producers and the users. Crushers must ensure their cost-effectiveness by enhancing the valuation of co-products (meals for rapeseed and sunflower, oil for soya) and improve their economies of scale. They also strongly rely on grain imports because of a lack of French supplies (rapeseed and soybean particularly). As for feed manufacturers, the new organic regulation for January 2022 brings even more constraints to reach the nutritional need for monogastric.
\end{abstract}

Keywords: organic / oilseed / protein crops / France / supply chain

Résumé - Panorama des filières françaises des oléagineux, protéagineux et légumes secs biologiques. Pour répondre à la demande croissante en produits biologiques en alimentation animale (tourteaux d'oléagineux, protéagineux) comme en alimentation humaine (huiles végétales, légumes secs), les surfaces d'oléoprotéagineux et légumes secs biologiques augmentent fortement en France. Un diagnostic a été mené en 2016 et 2017 par Terres Univia, l'Interprofession des huiles et protéines végétales, sur les principales filières des oléagineux (soja, tournesol, colza, lin), des protéagineux (pois, féverole, lupin) et des légumes secs (lentille, pois-chiche) produites en agriculture biologique en France. Ce diagnostic s'appuie sur des enquêtes auprès des organismes collecteurs de graines et des premiers utilisateurs (triturateurs et fabricants d'aliments du bétail). Ce diagnostic a montré que les filières biologiques étaient déjà bien organisées mais qu'elles devaient faire face à de nombreux défis pour accompagner le changement d'échelle de la bio. Les collecteurs doivent assurer des débouchés et des prix aux producteurs en les accompagnant dans le choix des assolements et la conduite technique des cultures. Une meilleure adéquation offredemande doit être trouvée, en accentuant la contractualisation en filière. Les triturateurs doivent assurer leur rentabilité en améliorant la valorisation des co-produits (tourteaux de colza et tournesol, huile de soja) et renforcer leur économie d'échelle. Ils sont également dépendant des importations de graines du fait d'un manque d'approvisionnement en graines oléagineuses françaises (et en particulier en soja et tournesol). Enfin, concernant les fabricants d'aliments du bétail, la nouvelle réglementation bio, qui entrera en vigueur en janvier 2022, va entrainer plus de contraintes encore pour répondre aux besoins nutritionnels des monogastriques.

Mots clés : biologique / oléoprotéagineux / France / filière

\footnotetext{
"Contribution to the Topical Issue "Organic foods in the oil \& protein crop supply chain / Le «Bio » dans la filière oléoprotéagineuse"

*Correspondence: c.canale@terresunivia.fr
} 


\section{Introduction}

In recent years, organic sectors grew quickly and seemed to scale up in France. To face the increasing demand for organic food products, the entire supply chain had to adapt. To better understand and support the organic oilseed and protein crops development, Terres Univia carried out a survey of seedcollecting organizations and first users (crusher and feed manufacturers) in 2016 and 2017. Thirty-seven operators were encountered throughout the country (Fig. 1), which represented more than $80 \%$ of the volumes targeted for this study (oilseed and protein crops collected, meals and oil), giving an excellent representativeness to the study. The most comprehensive figures acquired during the survey concern the year 2015 , on which the quantitative results, hereunder presented, have been based. Regarding qualitative data and information, the three years (2015-2017) have been considered in the presented study.

\section{High-increasing sector}

The consumption of organic products registers a strong growth in France. In five years, the value of purchases of organic food products has doubled, from 4.6 billion euros in 2013 to 9.7 billion euros in 2018 (including out-of-home catering) (Agence Bio, 2019). In 2018, around 5\% of the food household consumption is dedicated to organic food. The mass retail registers nearly a half $(49 \%)$ of the organic food products purchase, followed by the speciality stores (34\%) and the direct sales (12\%) (Agence Bio, 2019). While the sales in speciality stores grew more rapidly than the ones in mass retail between 2011 and 2016, the trends are reversing this last two years (Agence Bio, 2019). This dynamism shows the democratization that is underway in organic products consumption in France.

This popularity of organic food products is an opportunity for oils, dried vegetables, soyfood and most of all for the animal feed markets. Indeed, the consumption of organic animal products (meat, dairy, eggs) has nearly doubled between 2013 and 2018. To respond to this increasing demand, the organic compound feed production has also nearly doubled at the same time to reach 479000 tons in 2018 (La Coopération agricole alimentation animale, 2019). As a result, the demand for protein-rich raw material, and particularly for oilmeals, is intensifying in France.

This strength of the organic market benefits an also booming French organic production. Indeed, in 2018, more than 2 billion hectares are conducted in organic production, which represent $7.5 \%$ of the utilised agricultural land $(+1 \%$ versus 2017). The organic surfaces dedicated to field crops show the greatest increase between 2017 and 2018 (+31\%) but still represent barely $4.3 \%$ (around 500000 ha) of the utilised agricultural land of field crops in France in 2018 (Agence Bio, 2019).

Since 2013, oilseeds and protein crops surfaces led in organic farming increased rapidly. Indeed, the oilseed surfaces increased three-fold between 2013 and 2018 to reach 87000 hectares (Agence Bio, 2019) (Figs. 2 and 4). At the same time, the protein crops surfaces (pea, fababean and lupin) have doubled and pulses surfaces (lentil, chickpea) have nearly

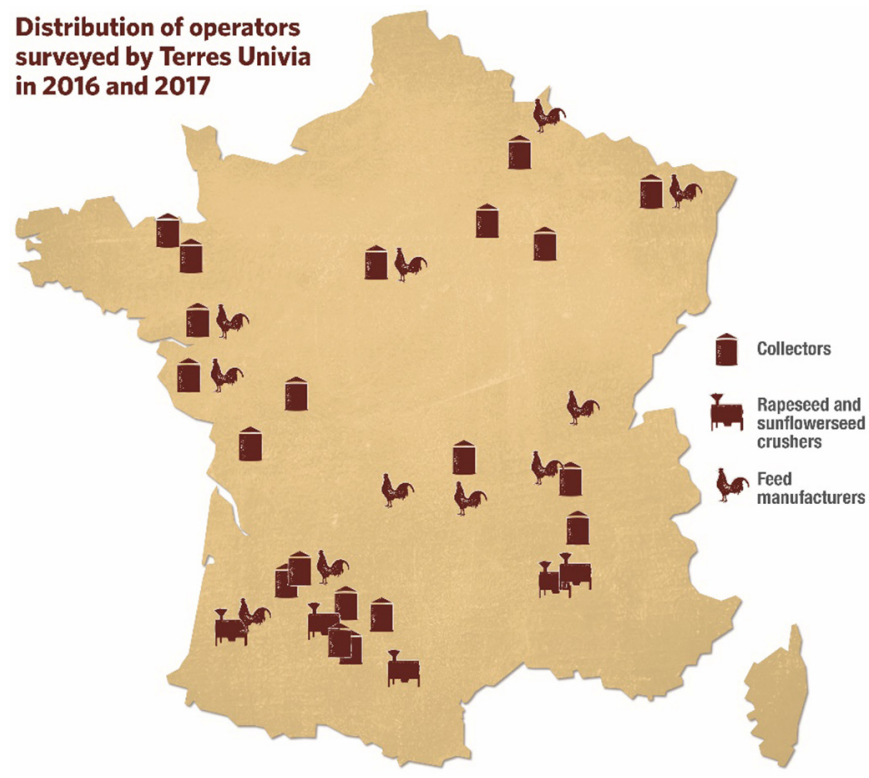

Fig. 1. Distribution of the encountered operators in 2016 and 2017. Source: Terres Univia.

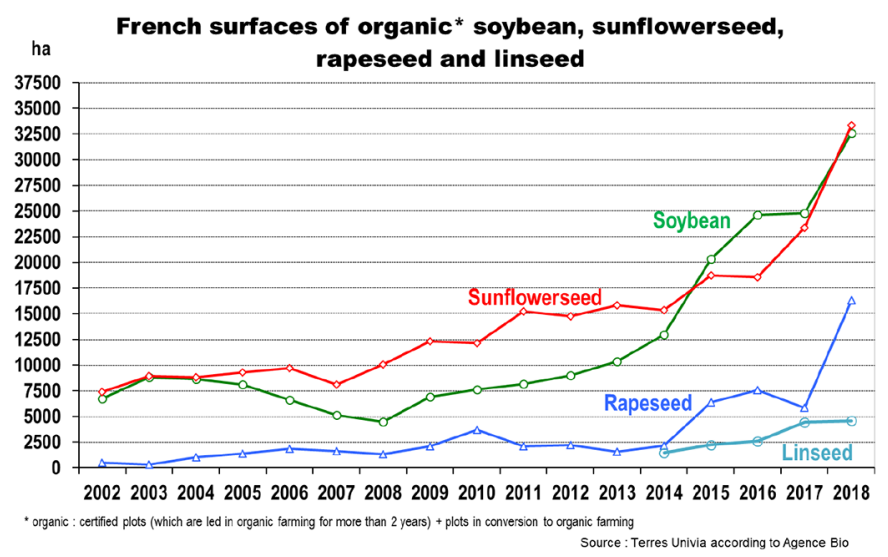

Fig. 2. French organic oilseeds development between 2002 and 2018. Source: Terres Univia according to Agence Bio.

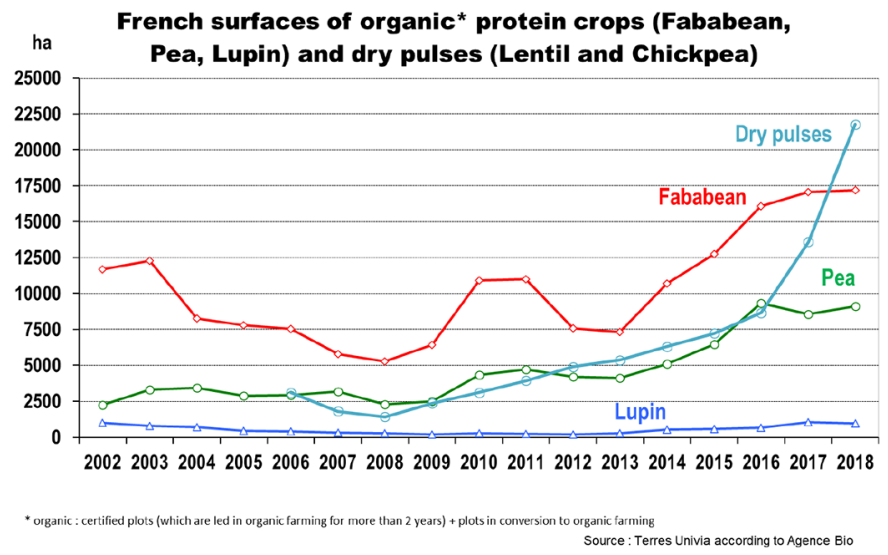

Fig. 3. French organic protein crops and dry pulses development between 2002 and 2018. Source: Terres Univia according to Agence Bio. 


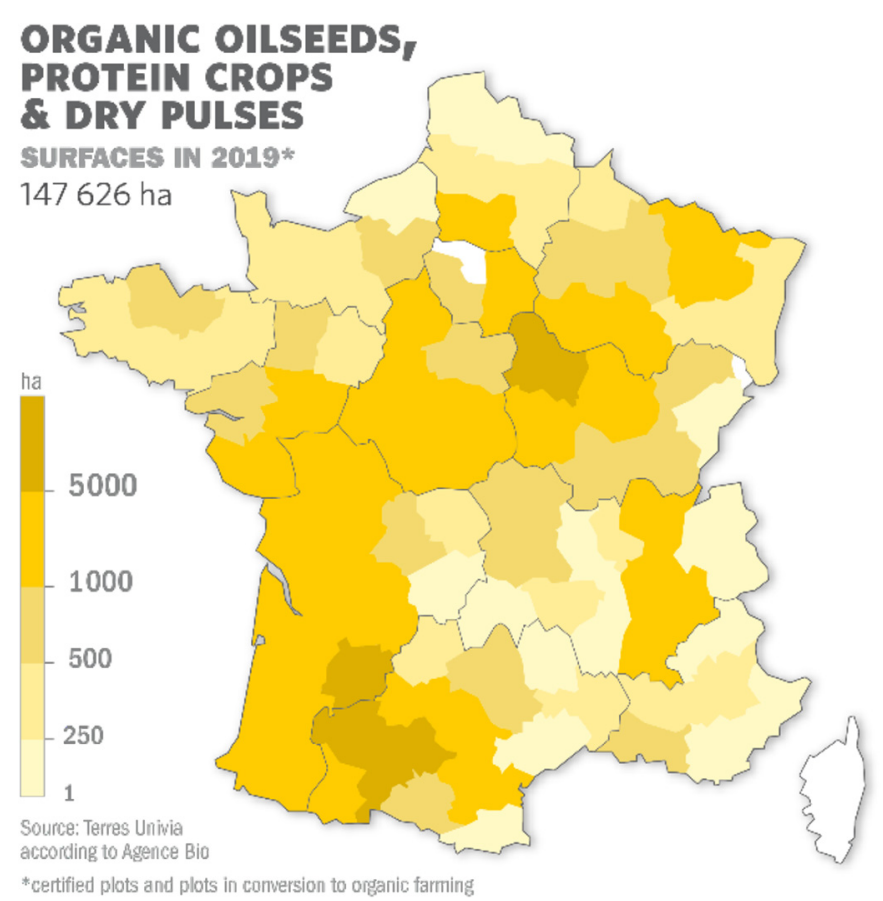

Fig. 4. Distribution of organic oilseeds, protein crops and dry pulses surfaces in France in 2019. Source: Terres Univia according to Agence Bio.

quadrupled to reach respectively around 31000 and 20000 hectares (Agence Bio, 2019) (Figs. 3 and 4). Mixed cereals-pulses surfaces (such as pea-wheat) are also increasing rapidly these past few years.

\section{Collection logistics specified to organic grain}

As it is specified in the regulation (EC) No. 889/2008 for organic production, "operators may simultaneously collect organic and non-organic products only when appropriate measures are taken to prevent any risk of mixing or exchanging organic and non-organic products and to ensure the identification of organic products".

That is why two profiles of organic collectors can be identified: those who collect only organic grains and have all their infrastructures and logistics dedicated for organic for a long time ago, and those who collect both organic and non-organic grains and have to dedicate parts of their infrastructures and logistics to organic grains, ensuring that there is no mix between the two types of grains (main profile). In the survey, we did not found any new elevator specializing on only organic production and market.

Because the organic sector is developing and still smaller than the conventional sector, infrastructures and equipment for handling and storing must be quite different: smaller grain storage cells at the delivery points, less intermediate silo for temporary storage. Moreover, the organic collectors must deal with more species. Indeed, long rotations are integral

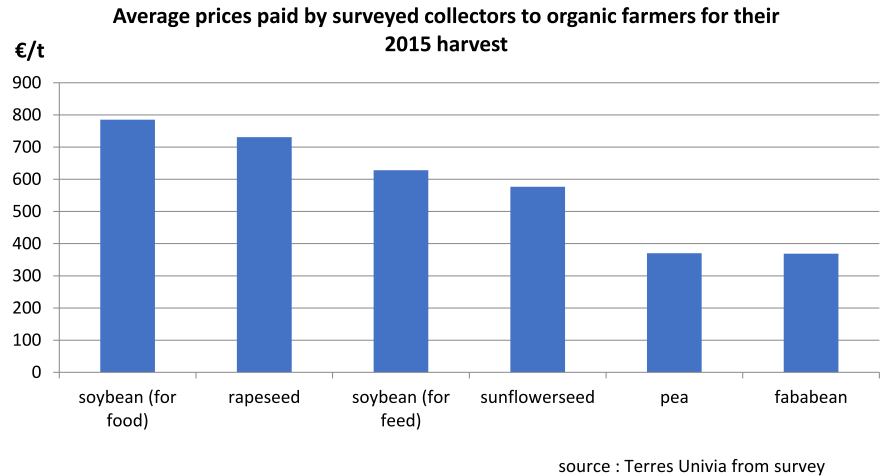

Fig. 5. Average prices paid by collectors to organic farmers for their 2015 harvest. Source: Terres Univia.

components of the organic farming system (including coarse grains), and organic farmers used to include in their rotations mixed cereals-pulses (for agronomic reasons such as pests and weeding control or nitrogen management). It involves, for collectors, many cells in each silo, adapted sorting tools and a great adaptability.

The grain processing is more complex and expensive, and it requires sorting tools that can deal with a great number of species and mixed species to meet the market quality requirements (for food and feed). Indeed, weed management can be more complex in organic farming, which induce heterogeneity in the delivered grain by the farmers and higher impurity levels. As a result, the intermediation cost is almost twice higher for organic grains than for conventional grains (between 60 and $90 €$ per tons for the "classic" oilseeds and protein crops, and far higher for the niche crops).

As for transport, organic farmers are less numerous and more spread out, that is why grains are generally carried from distant fields in small amounts to the collectors' sites, meaning more transport costs.

Annual production contracts between farmers and collectors like cooperatives are more popular in the organic supply chains. In fact, establishing contracts with farmer before sowing time allows the collectors to streamline their grain collection according to the market and reduce their logistic costs. For example, they can include positive lists of accepted mixed cereals-pulses for delivery or give advices to producers' rotation crops based on the market demand. And for the producers, it is a way of ensuring an outlet and a price for their productions. As for multi-years production contracts, it is still little used, but some collectors want to spread it to have a better visibility on their supplies.

Oilseed and protein crops prices for organic producers are significantly higher than the conventional ones. Grains valued in food either directly (lentils, chickpeas) or through one of the processing products (soyfood, sunflower and rapeseed oils) are the best paid (Fig. 5). On the contrary, peas and fababeans, only valued in animal feed, are less paid to the organic producers (Fig. 5) but still better than conventional ones. In fact, organic prices for pea and fababean amounted to $370 € / \mathrm{t}$ while conventional prices amounted respectively to $180 € / \mathrm{t}$ and $210 € / t$ for the 2015 harvest (FranceAgrimer, 2019). 


\section{Distribution North / South of the grain collection surveyed in 2015}

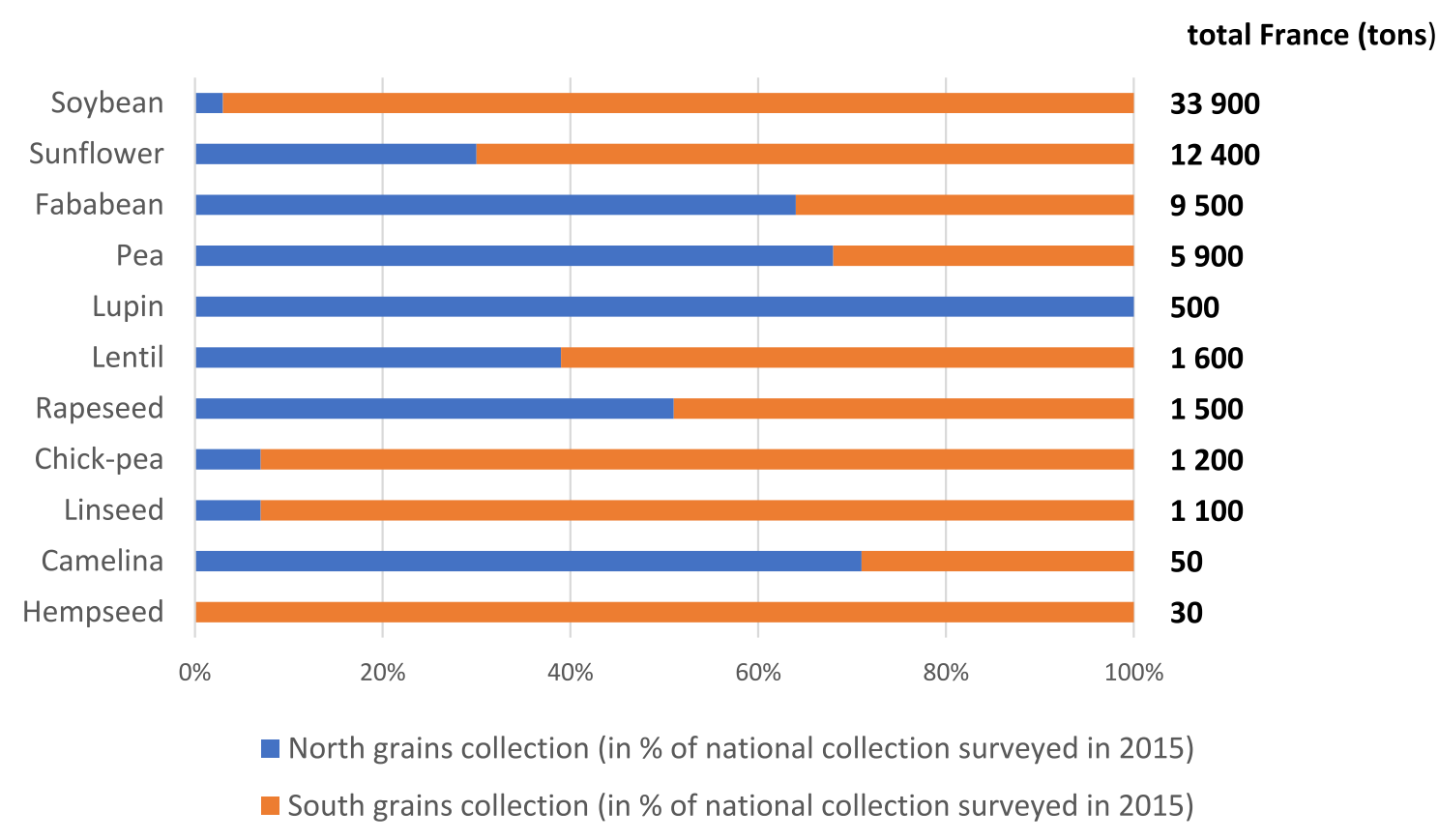

Fig. 6. Distribution North/South of the grain collection surveyed in 2015. Geographical areas were defined according to the old administrative French regions. South is compounded by the Provence-Alpes-Côte-d'Azur, Languedoc-Roussillon, Midi-Pyrénées, Aquitaine, Auvergne and Rhône-Alpes regions; North brings together the other regions. Source: Terres Univia.

\section{Supply mainly for domestic consumption}

Organic oilseeds and protein crops, like conventional ones, have two main outlets: feed and food. Peas, fababean and lupin are sold to French feed manufacturers (the mixed cerealslegumes collected are always sorted before sold). Sunflower seed, rapeseed and linseed are sold to French crushers whose activity is driven by food vegetable oil market. Soybeans have a dual market: $50 \%$ of the collected soybeans are sold to French and abroad soy manufacturers for food (soy juice, tofu, etc.) and $50 \%$ are sold to French soy crushers to produce soymeal for feed. As for lentils and chickpeas, they are sold directly after bagging or preparing and canning.

In food value chain, collectors and first users usually conclude annual contracts. Multi-year contracts are little used by rapeseed and sunflower seed cruschers who wants to keep up with market prices to be competitive.

In animal feed, manufacturers collaborate strongly with collectors. In fact, they often belong to the same group or, for the old organic stakeholders, they have been working together for a long time. Their relationship relies particularly on habit and trust.

The organic production of oilseeds and protein crops is not homogenous in France. Indeed, some species are mainly collected in the South of France (soybeans, sunflower seeds, chickpeas and lentils) while others are mainly collected in the North of France (peas, fababean and lupin) (Fig. 6). Users can thus be far from the collecting area of the grains they need. There are also logistic issues between collectors and users, including more expensive transport costs and plant supply can be more variable than in conventional.

\section{An insufficient French supply for oil manufacturers}

Sunflower seed and rapeseed crushers, often referred as vegetable oil manufacturers, are mainly settled in the South of France in the main oilseeds production areas. Indeed, sunflower seed, which is mainly collected in the South, is the most crushed grain (around $70 \%$ of the oilseed grain volumes surveyed). Both classic and high oleic sunflower seeds are crushed, with a dominance of high oleic in recent years. Rapeseed is the second crushed oilseed (around 25\% of the grain volumes). The remaining $5 \%$ of crushed grains are mainly linseed. Small volumes of hempseed and camelina are crushed by some vegetable oil manufacturers (Fig. 7).

As collectors, vegetable oil manufacturers can dedicate their activities to organic crush or crush both organic and nonorganic oilseeds by ensuring that there is no mix between the two types of products. They can use different production lines, or the same line for both organic and non-organic products provided that the tool is cleaned before organic crush. The cleaning consists in processing organic oilseed after the conventional ones and decommissioning the first oil obtained.

The vegetable oil manufacturers also differ from their crushing capacities. It mainly depends on the markets they choose to address and the sale strategies they adopt. In fact, some oilers, mostly small ones, sell their oil in bottles with their own brand through French specialized distribution networks (direct sales, specialized organic stores, delicatessen...). They generally choose to diversify their oil production with minor oilseeds such as linseed, hempseed and camelina seed, and with nuts (walnut, hazelnut, etc.). Others sell their oil 


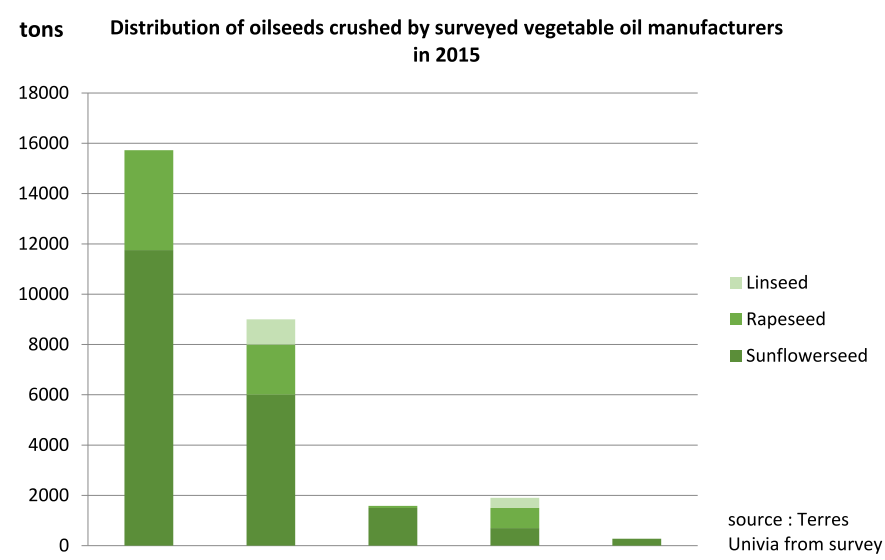

Fig. 7. Distribution of oilseeds crushed by vegetable oil manufacturers in 2015. Source: Terres Univia.

through French distribution brands or to agri-food manufacturers. They focus on volumes, allowing scale economies, rather than on diversification. Most of the oilers sells part of their oils to the export market (Europe but also Asia and Canada). It must be noted that, unlike the conventional one, organic oils are not intended for biofuel.

For their supplies, like for their sells, vegetable oil manufacturers are not bound to the basin where they are settled. Even if they are satisfied with the quality of French sunflower seed and rapeseed (in terms of grains moisture and oil contents), there is a lack of French availability. In fact, onethird of the sunflower seeds and three-quarter of the rapeseeds crushed by vegetable oil manufacturers are imported from European countries (Spain, Italy, Germany and The Netherlands for sunflower seeds and Romania and Italy for rapeseeds).

The use of solvent is not allowed in organic processes. Vegetable oil manufacturers use cold pressure to reach a good oil quality. However, the quality of the rape and sunflower meals obtained through this process remain variable in terms of proteins and fat contents. Sunflower meal protein content can be improved by shelling, but this process is not yet widespread for organic crushing. The main issue is the lack of valuable market for organic shells.

Sunflower and rapeseed meals are mainly sold to French feed manufacturers. Less frequently, vegetable oil manufacturers sell some of their meals to farmers, export it or grind it to make flour for gluten-free foods. Meals are often considered as a sub-product of oil production. Consequently, oilers focus on getting the highest value from their oil and not their meals.

\section{A well-managed soybean crushing process}

Unlike sunflower and rapeseed crushers, soybean crushers' activity is driven firstly by the valuation of the meals and not the oil due to the lower oil content and value soymeals are the main products obtained by crushing. Their high-protein content is interesting for organic feed manufacturers. That is why organic soybeans crushers are often bound to one or more feed manufacturers, which search for French, and qualitative soymeals supplies.

\section{Distribution of the feedstuffs outlets of the feed manufacturers surveyed in 2015}

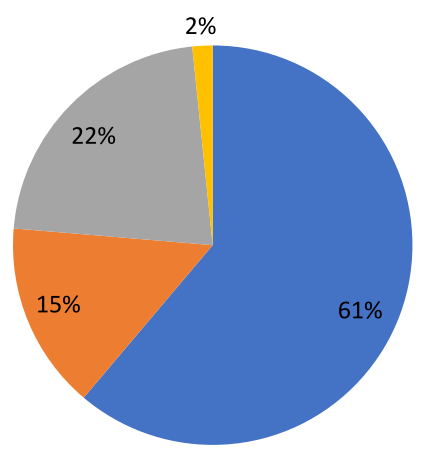

\author{
a Poultry \\ Pig \\ - Ruminant \\ Others \\ source : Terres \\ Univia from \\ survey
}

Fig. 8. Distribution of the feedstuffs outlets of the feed manufacturers surveyed in 2015. Source: Terres Univia.

As with vegetable oil manufacturers, the use of solvent is not allowed. But, because the soybeans crushers are more interesting in meals than oils, they use pressure-cooking process to obtain a good quality of meals (but deteriorating oils). Oils are mostly sold to feed manufacturers to enhance the palatability of feedstuff.

Because of a lack of French organic soybeans supplies, crushers must import from Europe (Italy) and Africa (Togo) through an organic traced chain. There is also a qualitative interest in importing from Togo: water content of soybeans is lower than French ones, allowing a better oil extraction and increasing the economical results.

\section{Strong regulatory and nutritional constraints for feed manufacturers}

Like for other operators, some feed manufacturers are dedicated to organic production, while others deal with organic and non-organic products. The latest often choose to dedicate one plant to organic production to split their organic and nonorganic activities.

Feed manufacturers mainly direct their production towards the poultry (mostly laying hens) market, which represent around two-thirds of the uses of feedstuffs in France. The ruminant organic feed market is less developed, but the demand for organic dairy and meat has been increasing recently. Other small markets show the diversity of outlets for organic feedstuff: fish, escargot, rabbit, and horse (Fig. 8).

The main issue for feed manufacturers is to reach the nutritional needs of livestock in amino acids (especially sulphur amino acids). Indeed, organic regulations prohibits the use of synthetic amino acid and restrict to $5 \%$ the incorporation of conventional high-proteins ingredients into monogastric rations (potato protein and corn starch). With the enter into force of the new organic regulation in January 2022, monogastric feed stuffs ought to be made with $100 \%$ of organic raw material, which will reinforce the issue for feed manufacturers to reach the nutritional needs of poultry. 


\section{Distribution of the raw feed used by the feed manufacturers surveyed in 2015}

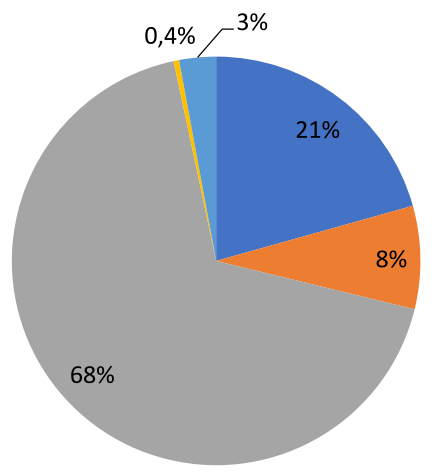

@ilmeals
Protein crops
Cereals
Oil
Other
source : Terres
Univia from
survey

Fig. 9. Distribution of the raw material used by the feed manufacturers surveyed in 2015. Source: Terres Univia.

The first raw feed used by organic feed manufacturers is cereal (like in conventional feed), follow by oilmeals $(20 \%)$ and peas and fababeans (almost 10\%) (Fig. 9).

Feed manufacturers are satisfied with the quality of French soymeals, which have a high content of protein. But they emphasize the variability of French sunflower meals quality due to the crushing process that differs between vegetable oil manufacturers. This variability and the low protein content of organic sunflower meals limit its use for feed. As for the use of French rapemeals, the lack of availability is the main drag for feed manufacturers, which are interested in this raw material because of its methionine contents. Organic feed manufacturers use a larger amount of pulses than the conventional one who uses around $0.5 \%$ of peas and fababeans (Céréopa, 2016/ 17). Indeed, the price of organic peas and fababeans is attractive regarding its protein contents. But their relatively low protein concentration and the presence of anti-nutritional factors do not allow feed manufacturers to incorporate more peas and fababeans in feedstuffs. This second issue can be solved by suitable varietal choice at farmer scale meanwhile the first one should be addressed in genetic and in processing $\mathrm{R} \& \mathrm{D}$ programs.
Most of the organic feed manufacturers are accustomed to work in a tense flow and make very few stocks. The supplies are under constraints due to the geographical remoteness of crushers and collectors and the lack of availability of organic raw material, especially soymeals. Feed manufacturers have to import oilmeals to reach their needs. The soymeals are mostly imported from India, China, and Europe (Italy, Spain) and, in lesser amount, from Africa and America (Brazil). The sunflower meals import come from European countries: Germany, Spain, Italy, and The Netherlands.

\section{Conclusions and prospects}

The increase of demand for organic products and organic surfaces require rapid adaptations of all the actors of the organic value chain. The oilseed and protein crops sectors are being structured in France to meet the demand of a growing market. Operators have to face some challenges to meet up with the scale up of organic sectors: crop management improvement, logistic and crushing plant rationalisation, adequacy supply/demand, technological process enhancement and supply chain stronger organization.

\section{References}

Agence Bio. 2019. Organic market and organic production in France. Available from https://www.agencebio.org/vos-outils/leschiffres-cles/ (accessed March, 2020).

Céréopa. 2016/17. Animal feed observatory, 2016/2017, focus on peas and cake. Available on request from Céréopa.

La Coopération agricole alimentation animale. 2019. Animal nutrition cooperatives, partners in the organic animal sector. Technical note 31/10/2019. Available on request from $\mathrm{La}$ Coopération agricole alimentation animale.

FranceAgrimer. 2019. Data and summaries, No. 7 November 2017. Prices paid to producers - results of the quarterly survey for the fourth quarter of the 2016/17 marketing year. Available from https://www.franceagrimer.fr/content/download/54725/document $/ 15+-+$ Enqu $\% \mathrm{C} 3 \%$ AAte + Donn $\% \mathrm{C} 3 \%$ A 9 es + et + BilansGrandes+cultures+Prix+trimestriels+nov+2017.pdf (accessed August, 2020).

Citethisarticleas: Canale C, Labalette F, Ruiz-Le Guillou C. 2021. Overview of the French organic sector of oilseeds and protein crops. OCL 28: 6 . 